\title{
模擬酸性雨試料の $\mathrm{pH}$ 測定結果
}

\section{1.はじめに}

酸性雨調查において pH 測定は, 酸性雨の影響を考 えたとき重要な項目の一つであり，市民団体の調査を 含め必須項目になっている. 最近の酸性雨調査は 1 降 水あるいはある期間の降水を採取する場合が多く，周 辺の大気污染を反映する降雨初期の試料に比べ希薄な 状態にある。このような試料は緩衝能が小さく，また 测定環境の影響等を受け，その $\mathrm{pH}$ 值が安定しにくい ことが指摘されている ${ }^{1,2)}$.

そこで，測定者が規定の希釈操作をしたとき，日本 の降水の平均的な濃度 ${ }^{3)}$ となるような模擬酸性雨試料 （以下, 試料という）を試薬から作成し, 酸性雨調査 における $\mathrm{pH}$ 測定の精度を検討した。

\section{2. 方法}

\section{1 模擬酸性雨濃厚液の調製及び配布}

模擬酸性雨濃厚液は表 1 に示す組成に調製し，この 酸性雨濃厚液を $10 \mathrm{ml}$ づつプラスチック容器にとり, 環 境庁（委託先：(財)日本環境衛生センター）が各測定機 関に郵送で配布した。

\section{2 参加機関}

参加機関は, 都道府県及び政令指定市の酸性雨調査 担当機関 (66機関) とした。

\section{3 模擬酸性雨試料の調製}

各測定機関は配布された模擬酸性雨濃厚液の全量を 精製水で $1 \ell$ とし, 試料とした。

\section{表 1 模擬酸性雨濃厚液の組成}

\begin{tabular}{|c|c|c|c|c|c|}
\hline $\mathrm{NaCl}$ & $\mathrm{KNO}_{3}$ & $\begin{array}{r}\mathrm{CaSO} \\
\text { 塩m } \\
\end{array}$ & $\begin{array}{l}\mathrm{g}\left(\mathrm{NO}_{3}\right)_{2} \cdot 6 \mathrm{H}_{2} \mathrm{O} \\
\text { 刘水 } \mathrm{g}\end{array}$ & $\left(\mathrm{NH}_{4}\right)_{2} \mathrm{SO}_{4}$ & $\begin{array}{c}\mathrm{HNO}_{3} \mathrm{HCl} \\
\mathrm{mol} / \ell\end{array}$ \\
\hline 0.5 & 0.1 & 0.5 & 0.3 & 0.5 & $0.005 \quad 0.003$ \\
\hline
\end{tabular}

* 千葉県環境研究所 Toshio OSHIO

* * 環境庁大気保全局大気規制課 Jun SASAKI
押 尾 敏 夫*・佐々木

淳 $* *$

\section{2. $4 \mathrm{pH}$ の測定等}

試料の測定はガラス電極法とし, 基本的には各機関 が日常実施している操作方法により行った。

測定項目は, 機器校正後のほう酸塩 $\mathrm{pH}$ 標準液 $(\mathrm{pH}$ 9 標準液) の指示值, 試料の 3 分後および安定後の $\mathrm{pH}$ 值，測定温度である.

3. 結果

\section{3. $1 \mathrm{pH}$ 計の指示値の直線性について}

本調査では, $\mathrm{pH}$ 計の指示値の直線性をみるために $\mathrm{pH} 9$ 標準液の測定を行った。この標準液の測定を行っ た機関数は62機関あった．その結果を表 2 に示す．こ の標準液の $\mathrm{pH}$ 值の平均值は9.17, 標準偏差は 0.09 , 範囲は9.38〜8.88であった。この標準液の測定值が, 平均值士標準偏差の範囲を超える測定値を示した機関 数は 12 機関あり, $\mathrm{pH}$ 計の指示値の直線性が確保出来 ているとはいえない機関の比率は $19.4 \%$ でった。こ のうち, 高い方にずれた機関数は 7 機関 $(11.3 \%)$, 低い方にずれた機関数は 5 機関 $(8.1 \%)$ であった.

\section{2 模擬酸性雨試料の実測 $\mathrm{pH}$ 值}

表 2 に示したように試料の実測 $\mathrm{pH}$ 值の平均值は 4.15 , 標準偏差は 0.11 , 範囲は4.77〜3.89であった。 この試料の測定值が, 平均值士標準偏差の範囲を超え る測定值を示した機関数は 7 機関 (10.6\%) あった. このうち, 高い方にずれた機関数は 3 機関 $(4.5 \%)$

表 2 模擬酸性雨試料, $\mathrm{pH} 9$ 標準液の $\mathrm{pH}$ 測定 結果及び成分濃度から計算した $\mathrm{pH}$

\begin{tabular}{|c|c|c|c|c|}
\hline & \multicolumn{2}{|c|}{ 模擬酸性雨試料 } & \multirow[t]{2}{*}{ pH 9 標準液 } & \multirow[t]{2}{*}{ 計算値 } \\
\hline & 3 分後 & 安定後 & & \\
\hline 平均値 & 4.15 & 4.14 & 9.17 & 4.18 \\
\hline 標準偏差 & 0.11 & 0.05 & 0.09 & 0.11 \\
\hline 最高値 & 4.77 & 4.29 & 9.38 & 4.62 \\
\hline 最低値 & 3.89 & 3.96 & 8.88 & 3.99 \\
\hline 機関数 & 66 & 47 & 62 & 65 \\
\hline
\end{tabular}


あり,このうち 2 機関は 3 分間では安定した值が得ら れなかったが，安定後の測定值はこの範囲に入った． また，低い方にずれた機関数は 4 機関（6.1\%） あり， このうち 1 機関は 3 分間では安定した值が得られなかっ たが, 安定後の測定値はこの範囲に入り，1機関は安 定後の測定値を測定していない.

\section{4. 考察}

\section{4. $1 \mathrm{pH}$ 計の指示値の直線性について}

$\mathrm{pH}$ 值は J I S Z 8802-1984 の規定では $\mathrm{pH}$ 標準液 の $\mathrm{pH}$ 值を基準とし，比較電極（基準とする電極）と ガラス電極とによって測定される起電力から求める值 である．そのためこの測定においては機器の校正, 校 正用 $\mathrm{pH}$ 標準液の規格, 校正温度の变動, 指示值の直 線性などが一定の範囲内であることが必要である.

機器の校正については，その繰り返し性について J I S Z 8802では表 3 に示すように $\mathrm{pH}$ 計の性能に より $\pm 0.05 \mathrm{pH}$ から $\pm 0.1 \mathrm{pH}$ と規定しているので，こ の範囲に入るまで校正操作を繰り返す必要があるが, 現在の測定器は自動校正でありこの範囲を超えると校 正不能になるので今回の調查では回答を求めなかった.

校正用 $\mathrm{pH}$ 標準液については，6種類の $\mathrm{pH}$ 基準液 がJ I S K 0018-1983 からK 0023-1983によって規定さ れ, トレーサビリティのある $\mathrm{pH}$ 標準液の供給体制が 確立された．それぞれの $\mathrm{pH}$ 標準液には規格標準液と 調製標準液とがあり，前者はその $\mathrm{pH}$ 值が国によって 保証されている. 今回調査では, 使用した標準液が規 格標準液であるか調製標準液であるかの回答を求めな かった。

校正温度の変動については，J I S Z 8 8802 では $\mathrm{pH}$ 標準液の温度の測定精度は $\mathrm{pH}$ 計の性能により土 $0.1^{\circ} \mathrm{C}$ か $\pm 0.5^{\circ} \mathrm{C}$ 及び校正中の $\mathrm{pH}$ 標準液の温度の安 定性を $\pm 0.2^{\circ} \mathrm{C}$ 吅 $1{ }^{\circ} \mathrm{C}$ と規定している. 今回の調 査では測定試料数が 1 つであり変動が小さいことが想 定されたので，これに関する回答を求めなかった．

指示値の直線性については，J I S Z 8802では表 3 に示すにように $\mathrm{pH}$ 計の性能によって $\pm 0.03 \mathrm{pH}$ 以

表 $3 \mathrm{pH}$ 計の形式と繰り返し性及び直線性

\begin{tabular}{cccc}
\hline 形式 & 繰り返し性 & 直線性 & 使用する $\mathrm{pH}$ 標準液 \\
\hline 0 & \pm 0.005 & \pm 0.03 以内 & 規格 $\mathrm{pH}$ 標準液 1 種 \\
$\mathrm{I}$ & \pm 0.02 & \pm 0.03 以内 & 規格 $\mathrm{pH}$ 標準液 2 種 \\
& & & 又は調製 $\mathrm{pH}$ 標準液 \\
II & \pm 0.05 & \pm 0.06 以内 & " \\
III & \pm 0.1 & \pm 0.1 以内 & " \\
\hline
\end{tabular}

内から $\pm 0.1 \mathrm{pH}$ 以内と規定しているのでこれを確認 する必要があり，今回の調査では $\mathrm{pH} 9$ の標準液の測 定值の回答を求めた．その結果は調査機関全体を評価す ると，表2に示したように士のでみればJ I S Z 8802 に規定する形式正に相当する性能であった，また，最 高值・最低值の範囲でみれば 00.2 あり J I S Z 8802 に規定する範囲外であった。

直線性が確保できない大きな要因は，ガラス電極及 び増幅・表示部には検定制度が確立されているが比較 電極にはこの検定制度がないことから，比較電極の劣 化が考えられる，その理由として，最近の比較電極は 内部液に飽和 $\mathrm{KCl}$ 溶液を用いる形ではなく，0.33 $\mathrm{NKCl}$ 溶液を用いるのが一般的であり，これを純水中 に漬けて保存した場合，内部液が純水側に溶出し規定 の濃度（0.33N）と異なる状態になっていることが考 えられる。前述のように $\mathrm{pH}$ 值は $\mathrm{pH}$ 標準液の $\mathrm{pH}$ 值 を基準とし，比較電極とガラス電極とによって測定さ れる起電力から求める值であるから, 内部液の変質を 含め比較電極が劣化すると測定值に影響を与える．多 くの場合，この内部液を規定濃度のものに交換するこ とによって，直線性が破保できるようになる。

この直線性の確認については市販の $\mathrm{pH}$ 計のマニュ アルには記載がなく，何が原因であるかのチェック方 法も提示されていないので，今後このチェックおよび 改善法等の確立が必要である.

\section{2 模擬酸性雨試料の実測 $\mathrm{pH}$ 值}

試料は表 1 に示した模擬酸性雨濃厚液に加えた試薬 の量を100倍希釉した濃度であり，その期待される $\mathrm{pH}$ 值は4.10である. 今回の測定值の平均值はこの値に近 く, 全体でみれば産業公害防止協会 ${ }^{1)}$ やKoch ら ${ }^{4)}$ の 結果と同程度に精度よく測定されていた。しかし，3 分後の測定值では標準偏差が0.11及び平均値に対して 最高值が +0.62 , 最低值がー0.26であり, 安定後の測 定值では平均值でみれば 3 分後と差がないが, 標準偏 差が 0.05 と小さくなり, 平均值に対する最高值が +0.15 , 最低值がー 0.18 となり，3 分後に比べ両者とも小さく なった. Brennan らの検討によれば $\mathrm{pH} 4$ 〜 の試 料については䚌拌せずに 2 ～ 3 分で安定するとの報告 がある ${ }^{5)}$ が, 本調査では, 3 分間では試料と電極が充 分なじんでいなかったと推定され，今後この改善も必 要である，試料を筧找することは，試料と電極をなじ ませるのには効果があるが，同時に周辺環境の影響を も受けるので，試料量とも関係するが試料を入れ換え て 2 ないし 3 回測定するような形がよいのではないか 
と考えられる。

\section{3 成分濃度から計算した $\mathrm{pH}$ との比較}

溶液は電気的中性が保たれている。また，今回の試 料は希薄溶液であることから添加した成分は完全解離 しているあのと考えられる。 そこで, 測定されたイオ ン種濃度から計算した $\mathrm{pH}$ をみると表 2 に示したよう に, 平均値は試料の 3 分後の值よりやや高く, 標準偏 差は 3 分後と同じであった。しかし，平均值に対する 最高值は+0.34, 最低值は -0.18 と 3 分後と安定後の 中間的な結果之なり, イオン種の分析がイオンクロマ トグラフ法の普及により精度よく分析できる体制が整っ $た^{6)}$ ことから, 希薄溶液の $\mathrm{pH}$ 值はイオン種濃度から 計算することも有効であると考えられる，少なくとも， 計算 $\mathrm{pH}$ は測定された試料の実測 $\mathrm{pH}$ 值の妥当性の検 討には使用できるものと考えられる。

\section{5. ま と め}

日本の降水の平均的な濃度となるような模擬酸性雨 試料を試薬から作成し, $\mathrm{pH}$ 測定の精度を検討した結 果次のことがわかった。

1) $\mathrm{pH} 9$ 標準液で $\mathrm{pH}$ 計の指示值の直線性をみたと ころ, 直線性の確保 $( \pm 0.1 \mathrm{pH})$ が出来ているとはい えない機関の比率は19.4\%であった。このうち，高い 方にずれた機関は $11.3 \%$ ，低い方にずれた機関は 8.1 \%であり，今後このチェックおよび改善方法等の確立 が必要である.
2 ）試料の実測 $\mathrm{pH}$ 值は加えた試薬の濃度から期待さ れる $\mathrm{pH}$ 值に近い值であったが，測定時間が 3 分間で は不足の事例があり，試料と電極とをなじませる操作 が必要であると考えられた。

3）イオン種濃度分析値から計算した $\mathrm{pH}$ 值は試料の 実測 $\mathrm{pH}$ 值之一致し, 計算 $\mathrm{pH}$ 值は試料の実測 $\mathrm{pH}$ 值 の妥当性の検討に使用できる

\section{おわりに}

本調查は環境庁大気保全局大気規制課の酸性雨統一 精度管理調査結果のうち, $\mathrm{pH}$ 測定に関して取りまと めたものである.

\section{参 考 文 献}

1) (社)産業公害防止協会:「酸性降下物等二次粒子污染予測 手法開発研究調查報告書一捕集及び分析法の検討 - 」, 179 (1987)

2 ）沢田稔之佑，磯松幸貞： pH 測定における問題点について, 福井県公害センター年報, 12 （1982），175-185（1983）

3) 酸性雨調查法研究会:「酸性雨調查法」, ぎょうせい, 401 (1993)

4) Koch W F, G Marinenko, R Paule: $\mathrm{pH}$ measurments in rainwater. An interlaboratory test of $\mathrm{pH}$ measurments in rainwater. J Res Natl Bur Stand, 91(1), 23 32 (1986)

5) Brennan C J, M E Peden: Theory and practic in electrmetric determination of $\mathrm{pH}$ in precipitation. Atmos Environ, 21(4) 901-907 (1987)

6 ) 環境庁企画調整局環境研究技術課 : 平成 3 年度環境測定 分析統一精度管理調查結果, 243-279（1992）

\section{新刊案 内}

\section{食品衛生検査指針・追補 I 〈微生物編・理化学編・食品中の食品添加物分析法〉}

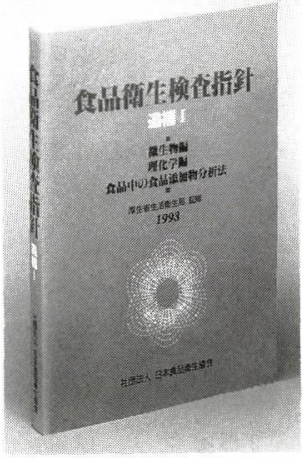

厚生省生活衛生局監修

B 5 判 350頁 定価7,500円（税込）送料380円

発行・申込み先 (社日本食品衛生協会 $(03-3403-2114)$

\section{一 概 要 —}

既刊本の食品衛生検査指針「微生物編」「理化学編」「食品中の食品添 加物分析法」の三編について, 社会的及び行政的ニーズに対応する最新 の試験法を追加収載しています. 